\title{
酸素消費を要因としたコンクリート中の鉄筋の腐食 に関する解析的考察
}

\author{
李 春鶴*1 ・ 松浪康行*2 ・栖原健太郎*3 $・$ 辻 幸和*4
}

\begin{abstract}
概要 : 鉄筋コンクリート構造物の鉄筋腐食において, 拡散による酸素量が鉄筋の酸化性腐食により消費される酸素量 より多いと, 鉄筋は酸化性腐食を継続するが, 高品質なコンクリートを用いて拡散による酸素量を少なくすると, 鉄 筋位置の酸素濃度は低下して腐食速度が減少寸る。本研究では, 酸化性腐食状態において消費される酸素量を考慮し た鉄筋コンクリート中の鉄筋の腐食についての解析モデルを提案する。そして, ケーススタディを行った結果, 酸素 拡散係数の小さい高品質なコンクリートを用いることにより, 鉄筋の腐食速度が小さくなり酸化性腐食状態から酸素 濃度の小さい還元性の腐食状態に移行できる可能性を報告する。
\end{abstract}

キーワード : 鉄筋腐食, 酸素拡散, 酸素消費量, 差分法, 還元性腐食

\section{1. はじめに}

鉄筋コンクリート構造物の鉄筋の腐食は，構造物の寿 命に関わる重要な問題である。腐食環境にある鉄筋コン クリート構造物を安全かつ計画的に使用するためには, コンクリートの品質および鉄筋の腐食状況の把握が不可 欠である。鉄筋コンクリート中の鉄筋はコンクリートの 中性化および塩害により不動態皮膜が破壊され, その後 鉄筋表面および近傍の水, 酸素の化学反応が生じて, 鉄 筋の腐食が進む 1)。腐食を定量的に計測し評価するには, 鉄筋表面および近傍における腐食因子の具体的な值が必 要であるが，実験的に直接それらの值を求めることは現 段階ではまだ不可能である。間接的な手法としては, 数々 の電気化学的な非破壊試験法が提案されているが, まだ 十分な方法であるとは言えない。

一方で, 原子力発電所の運転に伴って発生する放射能 レベルの比較的高い低レベル放射性廃棄物は, 地下 50〜 $100 \mathrm{~m}$ の深さに処分される計画がある。処分される金属 廃棄物と廃棄物を収納する金属製廃棄体容器, 処分施設 のコンクリート構築物に使われる鉄筋は低酸素濃度環境 においても腐食が進み，還元性環境での金属腐食が生じ

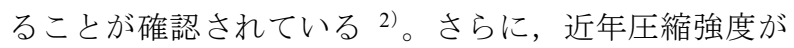
$100 \mathrm{~N} / \mathrm{mm}^{2}$ を超える高強度, 高品質なコンクリートが開 発され ${ }^{3)}$, 水と酸素などの拡散係数が極めて小さくなる
ものの, 鉄筋腐食のリスクは存在している。したがって, 高品質なコンクリートを用いた鉄筋コンクリート中の鉄 筋腐食速度の予測手法の確立が望まれる。

鉄筋コンクリート中の鉄筋の腐食についてのこれま での予測方法では，鉄筋腐食に大きな影響を及ぼす塩化 物イオンの移動を対象にした多くの有用な報告がなされ ている 4) 6)。また, コンクリート表面からは酸素が拡散 されて移動する現象を対象にした研究も報告されている が 7) 9) , 鉄筋の酸化性腐食により酸素が消費されること を考慮した報告はこれまでないようである。拡散による 酸素量が鉄筋の酸化性腐食により消費される酸素量より 多いと，鉄筋は酸化性腐食を継続するが，高品質なコン クリートを用いて拡散による酸素量を少なくすると，鉄 筋位置の酸素濃度は低下し, 腐食速度が減少する。

本研究では，鉄筋コンクリート中の鉄筋の腐食につい て, 酸化性腐食環境下における消費される酸素量を考慮 した推定モデルを提案する。そして，ケーススタディを 行った結果, 酸素拡散係数の小さい高品質なコンクリー 卜を用いることにより鉄筋の腐食速度が小さくなり，酸 化性腐食状態から低酸素濃度の還元性の腐食状態一移行 する可能性も示唆できることを報告する。

\section{2. 解析モデルの提案}



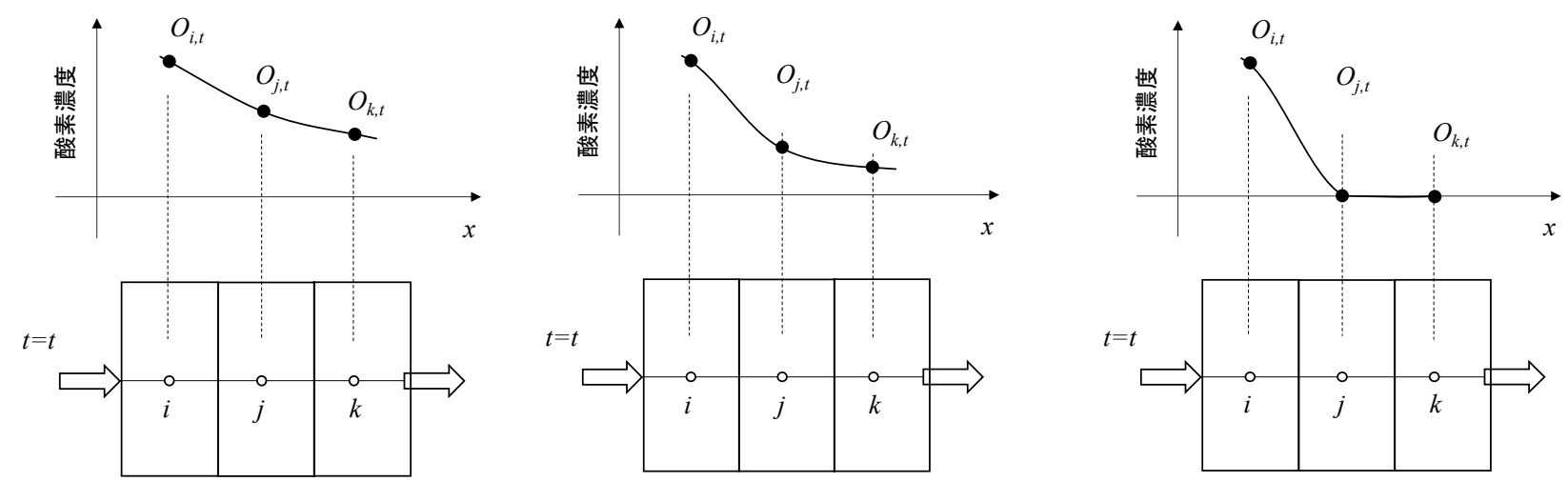

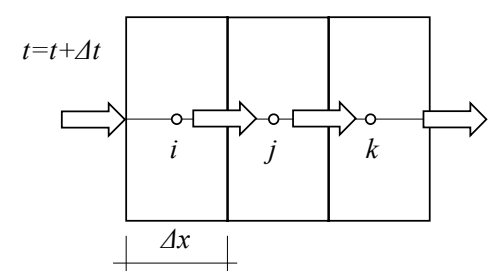

a）通常の拡散

（酸素消費なし）

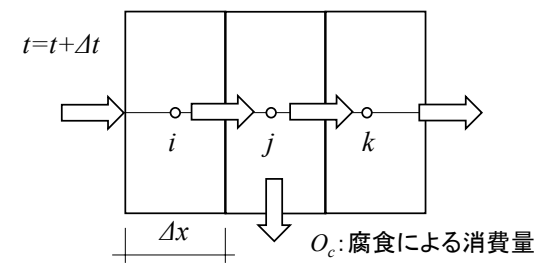

b）酸化性腐食により酸素を消費する場合 (酸素量が酸化性腐食による消費量よりも 大きい場合)

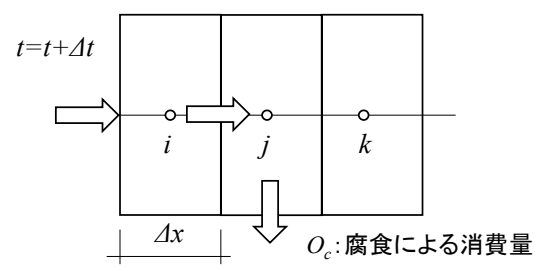

c）酸化性腐食により酸素を消費する場合 (酸素量が酸化性腐食による消費量よりも 小さい場合)

図-1 解析モデルと差分法による解法の概念

\section{1 解析モデルの概要}

（1）酸素拡散・消費モデル

鉄筋コンクリート部材における酸素の移動経路はコ ンクリート中の細孔であるが，細孔中に水が存在してい る場合と乾燥している場合では, 酸素拡散係数が格段に 変化する。さらに, 腐食反応に使用される酸素は水中に 溶解している状態であると考えられることから，外気か ら供給される酸素は経路上のどこかで必ず水に溶解する ことになる。したがって, 拡散移動時間は外気中での移 動時間と水中での移動時間の和である。その際, 酸素は 水の占める空間または空気の占める空間を通って拡散す るが, 気中の場合は水中の場合より $10^{4}$ から $10^{5}$ 倍も速い ため ${ }^{10)}$, 水中での移動は気中での移動に比べて無視でき ると考えられる。実際には, 含水率とかぶりコンクリー 卜の細孔構造によって水の状態は変化するが，水の分布 を精度よく推定するのは難しいこと, 細孔が完全に液状 水で占められているときの拡散係数のデータがない。そ のため, 拡散係数の值はマクロ的に, またはある含水率 での拡散係数である見かけの拡散係数という形で用いら れている。

コンクリート中の酸素の拡散は, コンクリート中の細 孔を拡散し, 以下の式(1)の拡散方程式に従うものと仮定 する。

$$
\frac{\partial O}{\partial t}=D_{o} \frac{\partial^{2} O}{\partial^{2} x^{2}}
$$

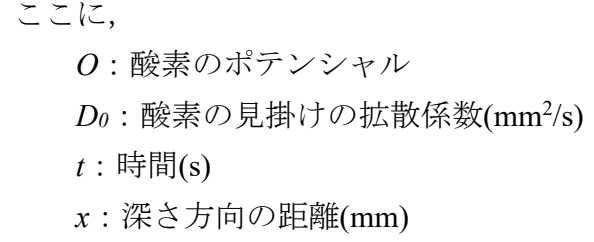

解析モデルは，(1)酸素が鉄筋コンクリートの表面から 内部一濃度拡散すること, (2)酸素が鉄筋に到達した場合, 鉄筋の酸化性腐食によって酸素が消費されること, (3)腐 食生成物により拡散係数には経時変化はないことをそれ ぞれ仮定する。

一次元の場合の概念図を図-1 a)に示す。モデルを酸素 の拡散方向に微小間隔 $\Delta x$ に分割した微小要素（以下， 要素と称する。）について, 時間 $t$ と $t+\Delta t$ の状態を考え ると, 式(1)の左辺および右辺は，それぞれ式(2)および式 (3)の差分を得る。

$$
\begin{aligned}
\frac{\partial O_{x, t}}{\partial t} & =\frac{O_{j, t+\Delta t}-O_{j, t}}{\Delta t} \\
\frac{\partial^{2} O_{x, t}}{\partial x^{2}} & =\frac{\partial}{\partial x}\left(\frac{\partial O_{x, t}}{\partial x}\right) \\
& =\left(\frac{O_{k, t}-O_{j, t}}{\Delta x}-\frac{O_{j, t}-O_{i, t}}{\Delta x}\right) / \Delta x \\
& =\frac{O_{k, t}+O_{i, t}-2 O_{j, t}}{\Delta x^{2}}
\end{aligned}
$$

式(2)と式(3)を式(1)に代入して整理すると，式(4)の差 
分方程式を得る。

$$
O_{j, t+\Delta t}=D_{o} \frac{\Delta t}{\Delta x^{2}}\left(O_{k, t}+O_{i, t}-2 O_{j, t}\right)+O_{j, t}
$$

なお, $D_{o}=\Delta x^{2} / 2 \Delta t$ の条件を式(4)に付加した場合, 式 (4)は式(5)に示すように簡略化できる。

$$
O_{j, t+\Delta t}=\frac{1}{2}\left(O_{k, t}+O_{i, t}\right)
$$

すなわち, $\Delta t$ 経過後の要素の酸素濃度は, $\Delta t$ 経過前 の隣接する要素の酸素濃度の平均であり, 式(5)の一回の 計算によって $\Delta t$ だけ時間ステップが進む。

次に，鉄筋のかぶり位置にある要素では，鉄筋の腐食 により酸素が消費されるため, 図-1 b）とc）に示す状態 となる。すなわち, 式(5)の酸素濃度を酸素量に変換する と式(6)となり，それの相関関係は式(7)で表せる。

$$
\begin{aligned}
& O_{m j, t+\Delta t}=\frac{1}{2}\left(O_{m k, t}+O_{m i, t}\right)-O_{c} \\
& O_{m x, t}=a \cdot V_{x} \cdot O_{x, t} \\
& \text { こに, } \\
& O_{x, t}: \text { 酸素濃度 }(\mathrm{mg} / \mathrm{L}) \\
& O_{m x, t}: \text { 酸素量 }(\mathrm{mg}) \\
& O_{c}: \text { 鉄筋のかぶり位置において, } \Delta t \text { における } \\
& \quad \text { 消費される酸素量 }(\mathrm{mg}) \\
& a: \text { 細孔量 }(\%) \\
& V_{x}: \text { 要素の体積 }\left(\mathrm{mm}^{3}\right)
\end{aligned}
$$

式(6)は, 鉄筋位置の要素に酸素が到達した場合, その 酸素量が鉄筋の酸化性腐食に消費されることを示す。そ して, 要素の酸素量が酸化性腐食に必要な酸素量より小 さい場合には, 図-1 c) に示すように, 要素に存在する 酸素量の分だけが酸化性腐食により消費され, その要素 の酸素量は零となる。一方, 酸素量が十分に存在する場 合には, 図-1 b）に示すように, 酸化性腐食により消費 した残り分が濃度拡散として作用する。

（2）酸素消費モデル

鉄筋の酸化性腐食による酸素消費量は，腐食速度から 求まる鉄筋の腐食量から, 鉄筋の酸化性腐食の反応式の モル比を用いて算定する。

腐食反応で生成した水酸化第一鉄 $\left(\mathrm{Fe}_{3} \mathrm{O}_{4}\right)$ ，水酸化鉄 ( II ) $\left(\mathrm{Fe}(\mathrm{OH})_{2}\right)$ は，周辺の酸素により酸化されてマグ ネタイト, 水酸化鉄 $(\mathrm{III})\left(\mathrm{Fe}_{3}(\mathrm{OH})_{3}\right)$, 酸化水酸化鉄 $(\mathrm{III})$ $(\mathrm{FeOOH})$, 、マタイト $\left(\mathrm{Fe}_{2}(\mathrm{OH})_{3}\right)$ 一変化するが, 鉄筋 周囲の様々な影響要因を受けるため, 厳密に定量化する のは難しい。そのため, 本研究では以下に示寸簡易的手
法を提案する。すなわち，鉄筋の腐食反応は，酸素が存 在する場合の酸化性腐食の酸素消費型腐食となり, 以下 の式(8)に示す反応式となる。

$$
\begin{gathered}
\mathrm{Fe}+1 / 2 \mathrm{O}_{2}+\mathrm{H}_{2} \mathrm{O} \Rightarrow \mathrm{Fe}(\mathrm{OH})_{2} \\
O_{c}=\frac{1}{2} \cdot \frac{M_{O_{2}}}{M_{F e}} \cdot n \cdot \lambda \cdot S_{s} \cdot \rho_{f} \\
\text { ここに, } \\
M_{O_{2}}: \text { 酸素のモル質量 }(32 \mathrm{~g} / \mathrm{mol}) \\
M_{F e}: \text { 鉄のモル質量 }(58.85 \mathrm{~g} / \mathrm{mol}) \\
n: \text { 鉄筋の本数 } \\
\lambda: \text { 鉄筋の酸化性腐食速度 }(\mathrm{mm} / \mathrm{s}) \\
S_{s}: \text { 鉄筋の表面積 }\left(\mathrm{mm}^{2}\right) \\
\rho_{f}: \text { 鉄筋の密度 }\left(7.8 \mathrm{mg} / \mathrm{mm}^{3}\right)
\end{gathered}
$$

なお, 数值計算においては, $\Delta t$ における消費量 $(\mathrm{mg} / \Delta t)$ に換算して用いる。また，酸化性腐食による酸素消費量 は，腐食速度の值にかかわるものの，酸素の供給量が小 さい場合は，鉄筋の酸化性腐食反応が酸素律速になり， 酸素の供給量により腐食速度を求めることができる。な お，低酸素濃度のいわゆる還元性腐食の炭素鋼の腐食速 度は，アルカリ条件において $0.1 \mu \mathrm{m} / \mathrm{y}$ 以下であることが 報告されている2，11。

これらの仮定により，図-1で述べたように，要素の酸 素量 $O_{m x, t}$ が消費量 $O_{c}$ よりも大きい場合には，腐食に必 要な酸素が要素に十分に存在する場合であり, 式(6)がそ のまま適用できる。しかしながら, 要素の酸素量 $O_{m x, t}$ が消費量 $O_{c}$ よりも小さい場合には, 要素の酸素量 $O_{m x, t}$ の分しか腐食しない。したがって, 消費量 $O_{c}$ は要素の酸 素量 $O_{m x, t}$ と同值となり, $\Delta t$ 後の要素の $\Delta x$ 以遠の要素の 酸素量は零となる。

\section{（３）コンクリート表面の酸素濃度}

1 気圧の条件下における酸素濃度は酸素の密度 $(1.429 \mathrm{~g} / \mathrm{L})$ と空気中の酸素の体積割合 $(21 \%)$ を用いて 求めると $O_{0}=300 \mathrm{mg} / \mathrm{L}$ である。これがコンクリート表面 の酸素濃度であり，拡散における初期值とする。

\section{2 解析手法}

解析対象物を図-2 に示す。解析の対象は $1000 \mathrm{~mm} \times$ $1000 \mathrm{~mm} \times$ 奥行のコンクリートに，かぶり C の鉄筋を 5 本配置した鉄筋コンクリート部材とする。解析モデルは, コンクリート表面から酸素の拡散方向である深さ方向に 厚さ $\Delta x$ で分割した 1 次元の積層モデルを採用する。

解析に用いた解析条件および解析パラメータを，それ ぞれ表-1 および表-2 に示す。なお, 酸素拡散係数の選定 においては，高品質なコンクリートに対する酸素拡散係 数の実測值がまだ報告されていないため, 現存する緻密 なコンクリートと言われている第一大戸川橋梁 12) の標 準桁についての酸素拡散係数である $7.2 \times 10^{-5} \mathrm{~cm}^{2} / \mathrm{s}$ 程度 ${ }^{13)}$ 


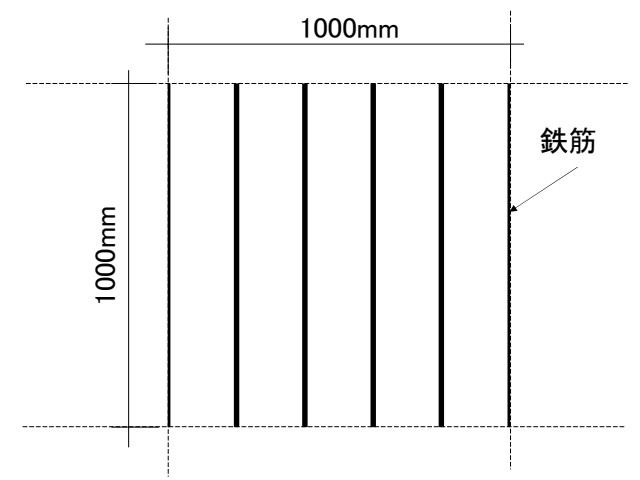

a) 平面図

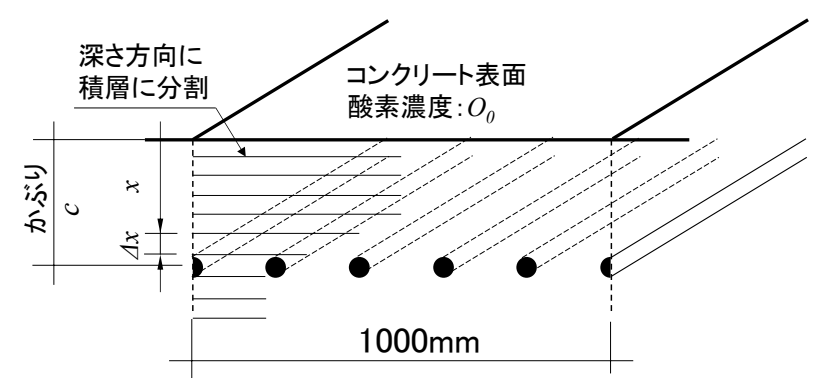

b） 一次元の積層モデル

図-2＼cjkstart差分法による解析モデル

表-1 解析条件

\begin{tabular}{l|l}
\hline \multicolumn{1}{c|}{ 条件 } & \multicolumn{1}{c}{ 備考 } \\
\hline 試算ブロックの形状寸法 & $1000 \mathrm{~mm} \times 1000 \mathrm{~mm} \times$ 奥行 $(300 \sim 5000 \mathrm{~mm})$ \\
\hline 鉄筋の配置 & 5 本 \\
\hline コンクリート要素の厚さ: $\Delta x$ & $5 \mathrm{~mm}$ \\
\hline コンクリートの空隙率 & $4.0 \%$ \\
\hline コンクリートの表面の酸素濃度 & $300.0 \mathrm{mg} / \mathrm{L}$ \\
\hline
\end{tabular}

表-2 解析パラメータ

\begin{tabular}{l|l|c}
\hline \multicolumn{1}{c|}{ 要因 } & \multicolumn{1}{|c|}{ 值 } & 水準 \\
\hline 酸素の拡散係数 $\left(\mathrm{cm}^{2} / \mathrm{s}\right)$ & $5.0 \times 10^{-3}, 5.0 \times 10^{-4}, 5.0 \times 10^{-5}, 5.0 \times 10^{-6}, 1.0 \times 10^{-6}, 5.0 \times 10^{-7}, 5.0 \times 10^{-8}$ & 7 \\
\hline 鉄筋の呼び名 & $\mathrm{D} 13, \mathrm{D} 19, \mathrm{D} 25$ & 3 \\
\hline 鉄筋のかぶり $(\mathrm{mm})$ & $30,50,90,130$ & 4 \\
\hline 酸化性腐食速度 $(\mu \mathrm{m} / \mathrm{y})$ & $1,10,100$ & 3 \\
\hline
\end{tabular}

を基準として，さらに高品質なコンクリートを想定した 酸素拡散係数についても用いる。酸化性腐食速度の選定 については，前述した還元性腐食の報告 2）,11）と既往の

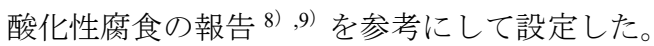

\section{3. 解析結果および考察}

\section{1 コンクリートの酸素濃度分布}

図-3に解析結果の一例として，コンクリート表面から の距離と酸素濃度の関係を, 経過時間が 3 年および 100 年について示す。酸素の拡散係数が $5.0 \times 10^{-6} \mathrm{~cm}^{2} / \mathrm{s}$ および $5.0 \times 10^{-7} \mathrm{~cm}^{2} / \mathrm{s}$ について, 腐食速度が $1 \mu \mathrm{m} / \mathrm{y}$, 鉄筋のかぶ
りが 90mm で，鉄筋の呼び名が D13，D19，D25 の場合 である。なお，酸素濃度はコンクリート表面の酸素濃度 300mg/L を 100\%として表している。

酸素の拡散係数が $5.0 \times 10^{-6} \mathrm{~cm}^{2} / \mathrm{s}$ のコンクリートについ て，酸素消費がない拡散に対して，鉄筋の酸化性腐食に よる酸素消費を考慮した D13，D19 および D25 を用いた 場合では，90mm のかぶり位置において曲線の勾配が変 化し，酸素が消費されていることが確認できる。鉄筋の 腐食速度を $1 \mu \mathrm{m} / \mathrm{y}$ と鉄筋の径にかかわらず一定と仮定し ているため，鉄筋の表面積の大きい D25 の消費量が多く なっている。そして，鉄筋位置における酸化性腐食の酸 素消費量に対して，コンクリート表面からの酸素の拡散 


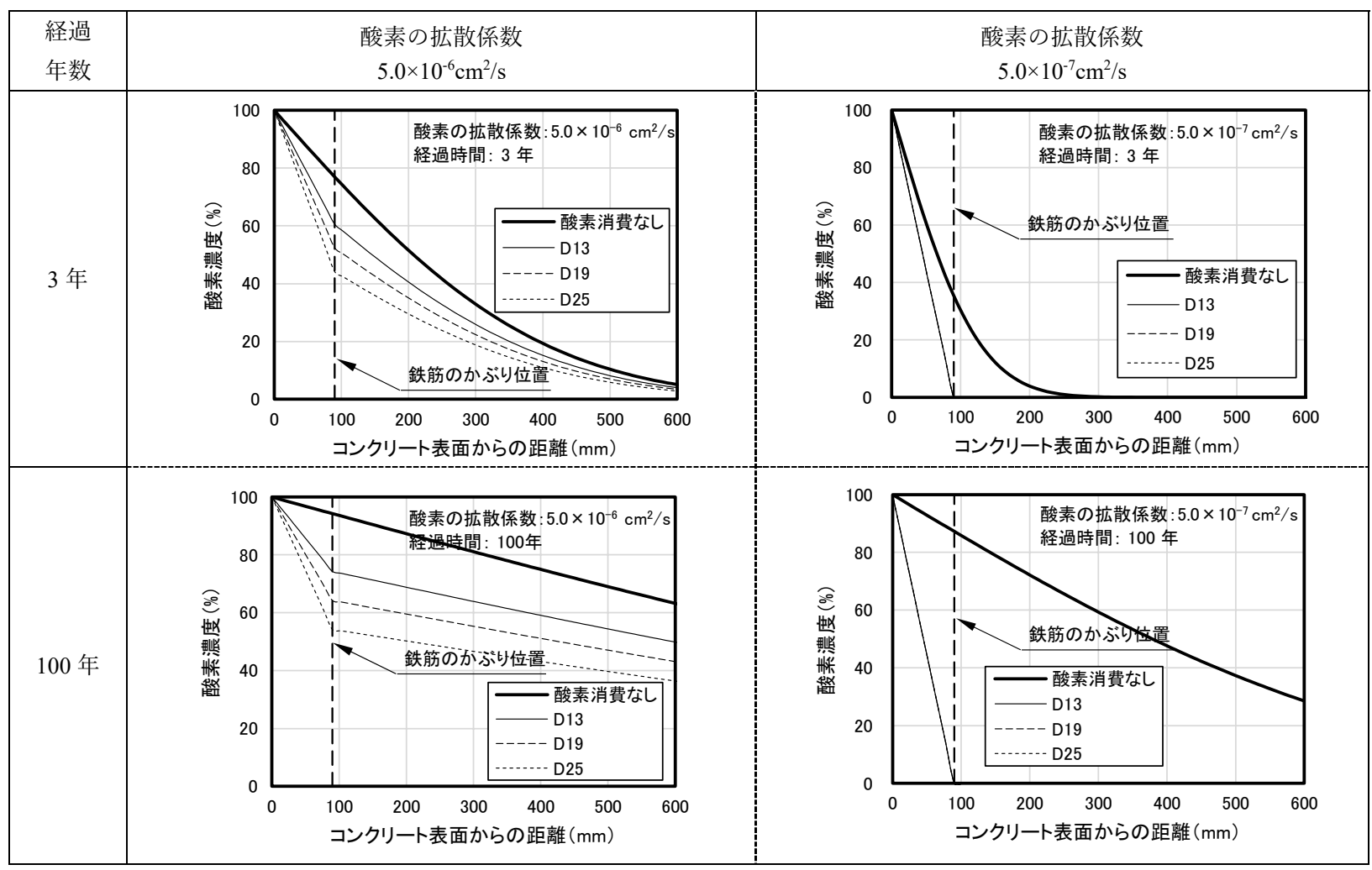

図-3＼cjkstart酸素濃度の分布

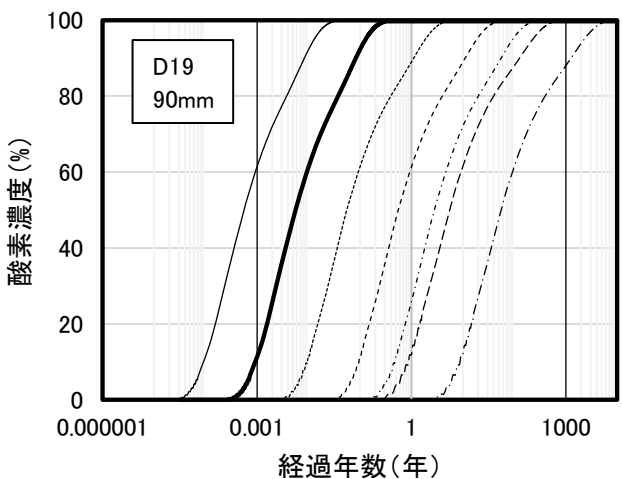

a) 腐食による酸素消費のない場合

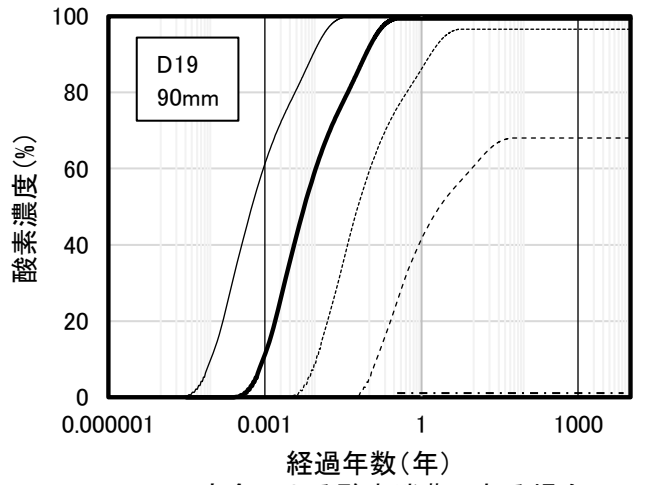

b) 腐食による酸素消費のある場合

図-4かぶり位置における酸素濃度の経時変化

による供給量が酸素消費量を上回っており，酸素が鉄筋 のかぶりよりもさらに奥の方へ拡散する。

酸素の拡散係数が $5.0 \times 10^{-7} \mathrm{~cm}^{2} / \mathrm{s}$ のコンクリートでは, コンクリート表面からの酸素の拡散に比べて, D13 だけ ではなくD19 とD25 の鉄筋のがぶり位置における酸化性 腐食の酸素消費量が酸素の供給量を上回って，いずれの 鉄筋も 1 本の重なった線で示される。そして, 3 年経過 後においても酸素がかぶりの $90 \mathrm{~mm}$ より奥へは拡散して いないことが確認できる。すなわち, 供給された酸素量 の分だけが鉄筋の酸化性腐食として消費されることにな る。

\section{2 かぶり位置の酸素濃度の経時変化}

図-4 は，かぶり位置の酸素濃度の経時変化を示す一例
である。基準となる腐食速度が $1 \mu \mathrm{m} / \mathrm{y}$ ，鉄筋の呼び名が D19，鉄筋のかぶりが $90 \mathrm{~mm}$ の場合である。なお，酸素 濃度は, 図-3 と同じコンクリート表面の $300 \mathrm{mg} / \mathrm{L}$ を $100 \%$ として表記している。a）図は鉄筋の腐食による酸素消 費のない拡散を，b）図は鉄筋の腐食による酸素の消費 を考慮した場合である。

a）図に示すように，かぶり位置における酸素濃度が コンクリート表面の酸素濃度に至る時間は，濃度酸素の 拡散係数が小さくなるほど長くなる。そして, 酸素の拡 散係数が $5 \times 10^{-8} \mathrm{~cm}^{2} / \mathrm{s}$ と非常に小さい緻密なコンクリー 卜の場合であっても, 酸素消費のないa) 図の拡散では, 最終的にかぶり位置の酸素濃度はコンクリート表面の酸 素濃度と同じ濃度となる。 


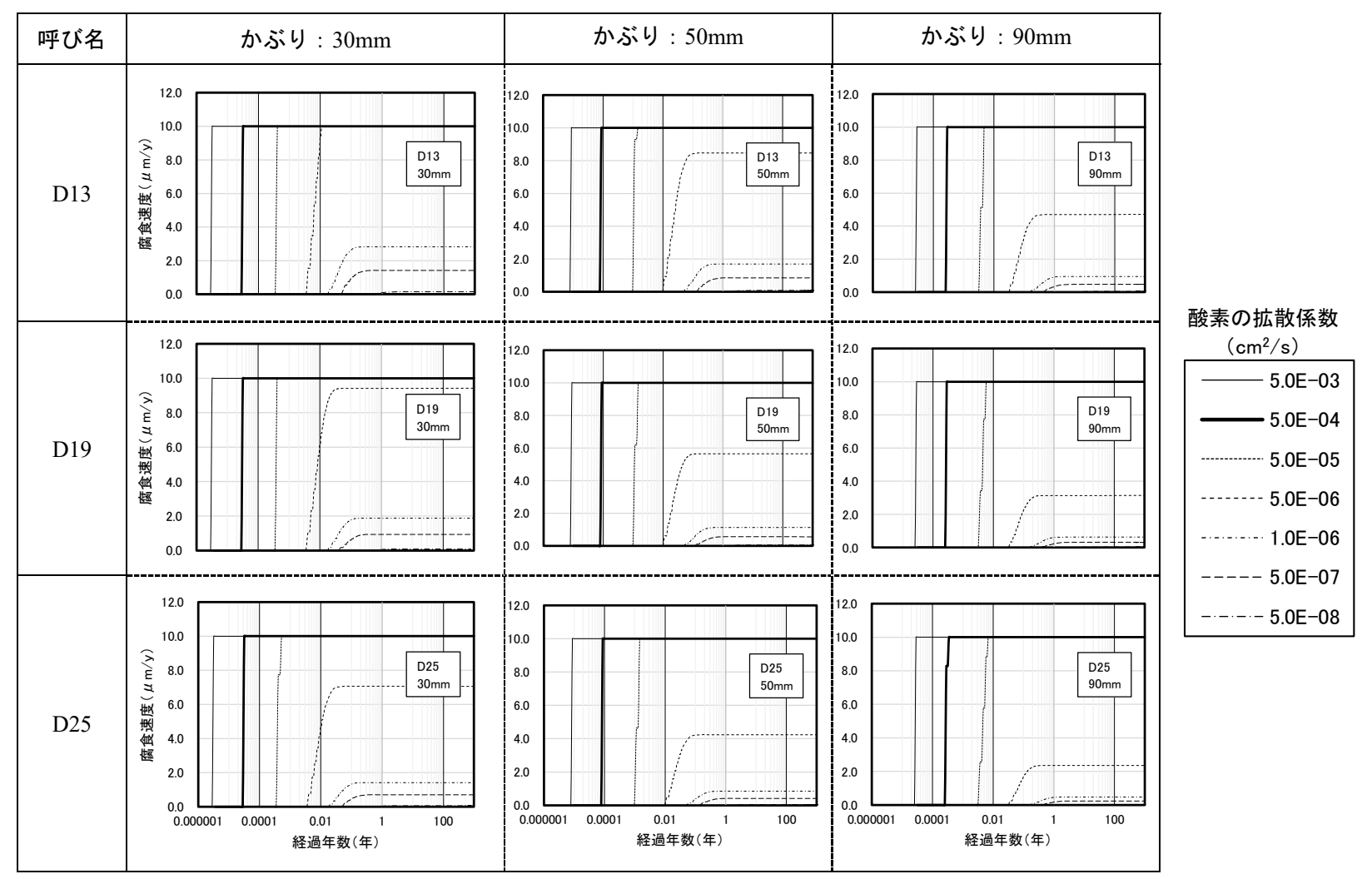

図-5 腐食速度の経時変化（基準となる酸化性腐食速度 $10 \mu \mathrm{m} / \mathrm{y}$ ）

一方で，b）図に示す酸素の拡散係数が $5 \times 10^{-5}$ ～ $5 \times 10^{-6} \mathrm{~cm}^{2} / \mathrm{s}$ 程度のコンクリートでは, かぶり位置におけ る鉄筋の腐食による酸素の消費量が拡散による供給量を 上回り, 時間経過とともに酸素濃度が増加するものの, その程度は低下して，ある濃度にとどまっている。供給 された酸素量に相当する腐食しか生じないためであり, 腐食速度が基準となる腐食速度よりも小さい值となる。 すなわち, 鉄筋腐食反応は酸素律速になり, 設定した基 準となる腐食速度 $(1 \mu \mathrm{m} / \mathrm{y})$ を保つために必要な酸素供 給量が不足している状態にある。そのため, かぶり位置 ではコンクリート表面の酸素濃度を下まわる濃度にとど まっている。そして，コンクリートの酸素の拡散係数が $1 \times 10^{-6} \sim 5 \times 10^{-8} \mathrm{~cm}^{2} / \mathrm{s}$ の 3 水準では, 供給された酸素量の すべてが腐食により消費される状態で, 酸素濃度が零と なる。なお，図中のグラフでは，これら 3 本の線がわか りやすいように, 零よりも少し大きい位置で表記してい る。

\section{3 鉄筋の腐食速度}

図-5には，鉄筋の腐食速度の経時変化を試算した結果 の例を示す。基準となる腐食速度が $10 \mu \mathrm{m} / \mathrm{y}$ の場合であ る。酸化性腐食状態における鉄筋は, 酸素を消費して腐 食を生じる。拡散による酸素の供給量に対して腐食によ る酸素の消費量が小さい場合には, 腐食に十分な酸素が 存在する状態であり, 鉄筋の腐食速度は基準となる腐食 速度となる。一方, 酸素の供給量 $O_{i}$ が酸素の消費量 $O_{c}$
よりも小さい場合には，供給された分に対応する腐食し か生じない。供給された酸素量を基に，式(8)のモル比に よって腐食量を算出し, 式(9)の鉄筋の酸化性腐食速度 $\lambda$ を逆算して求めた。

酸素の拡散係数が大きいコンクリートは，かなり早い 段階で鉄筋のかぶり位置に十分な酸素が供給される状態 となり，基準となる鉄筋の腐食速度に達寸る。一方，酸 素の拡散係数が小さいコンクリートは，かぶり位置に十 分な酸素が供給されず，基準となる鉄筋の腐食速度に必 要な酸素が不足するため, 供給された酸素分だけの鉄筋 の腐食速度となる。以降は，この鉄筋の腐食速度を腐食 速度の終局值と称する。

図-5より，次のことがいえる。

1 ）かぶりの影響

同一の呼び名の鉄筋について，かぶりが大きくなるに したがって, 酸素の供給距離が長くなる。そのため, 酸 素の供給量が不足し, 酸素の拡散係数が小さいコンクリ 一トほど，腐食速度の終局值が小さくなる。

2 ）鉄筋の呼び名の影響

同一のかぶりにおいて，鉄筋の呼び名が大きいものほ ど，鉄筋の腐食面積が大きくなる。そのため，酸素の消 費量が増加し, 酸素の拡散係数が小さいコンクリートほ ぞ，腐食速度の終局值が小さくなる。

\section{4 腐食速度の終局值}




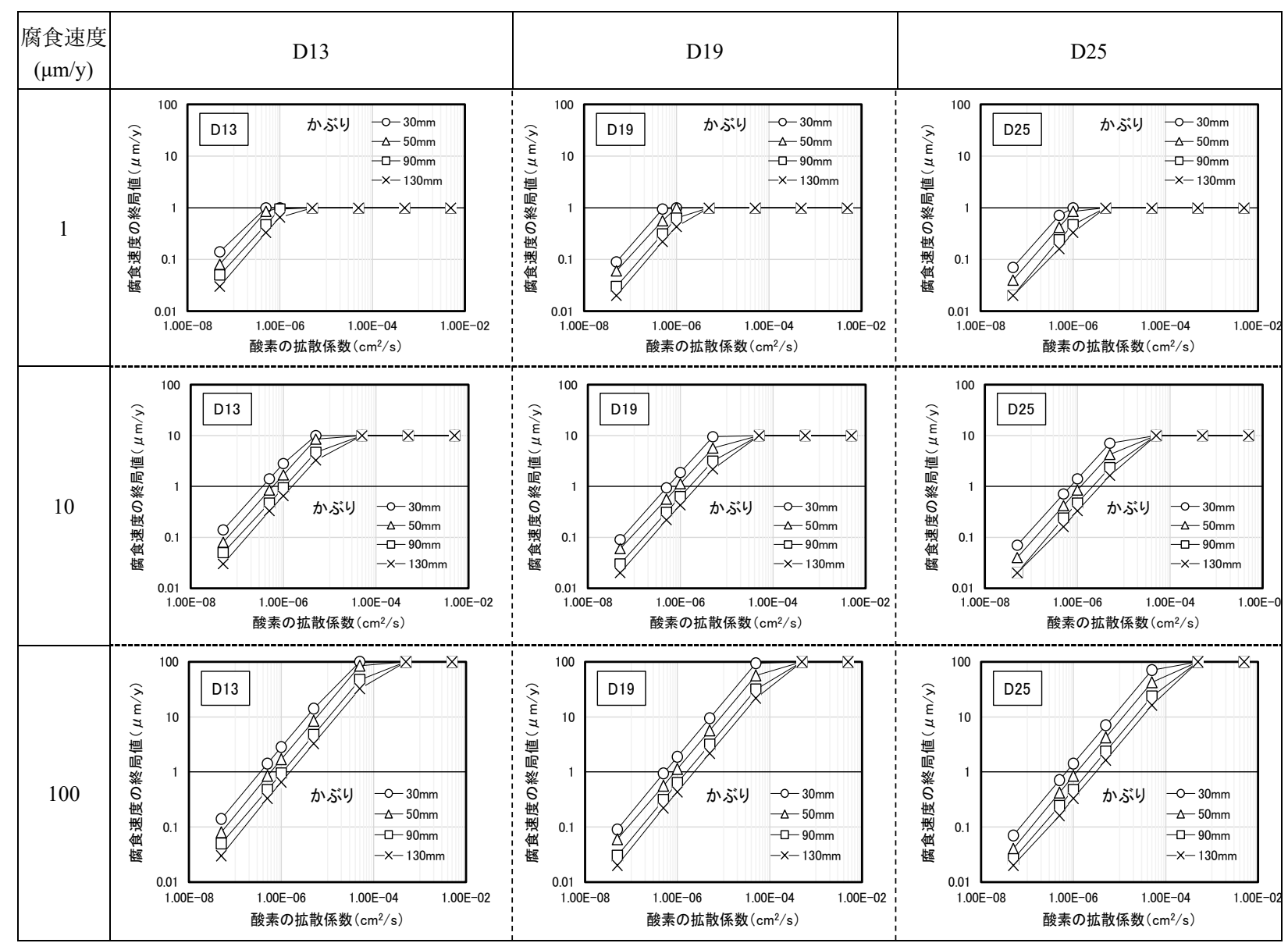

図-6＼cjkstart腐食速度の終局值

図-5に示した鉄筋の腐食速度の経時変化から，腐食速 度が一定となったときの值を腐食速度の終局值として, 基準となる腐食速度ごとにまとめたのを図-6に示す。縦 軸と横軸を対数で表示している。

酸素の拡散係数が大きいコンクリートは，かなり早い 段階で鉄筋のかぶり位置に十分な酸素が供給される状態 となり，基準となる腐食速度に達する。一方で，拡散係 数が小さいコンクリートは, かぶり位置に十分な酸素が 供給されず，基準となる腐食速度に必要な酸素が不足す る。そのため, 供給された酸素分に応じた腐食速度の終 局值となる。

鉄筋のかぶりと基準となる腐食速度ごとにそれぞれ の酸素の拡散係数を横軸にとり, 腐食速度の終局值を示 したのが図-7 である。鉄筋の呼び名 D13 について，かぶ りごとの腐食速度の終局值を比較した例である。鉄筋の 呼び名とかぶりが同じの場合, 酸素の供給に対して腐食 による消費が上回っている状態における腐食速度の終局 值は, 基準となる腐食速度が異なっていても, 同一の直 線上にプロットされる。酸素の供給が一定の条件で基準 となる腐食速度が異なるだけでは, 酸素の供給分しか腐 食しない状態となっているためである。

図-7 のかぶりの異なる 4 つ図を, かぶりごとに色分 けして,1つのグラフにしたものが図-8のa) 図である。
かぶりが大きいものほど，酸素供給の距離が長くなるた め，腐食速度の終局值が小さい方向に移行していること が明確になる。

同様の操作を鉄筋の呼び名 D19およびD25に適用した ものが，それぞれ b）図および c）図である。鉄筋の呼 び名が大きくなると，表面積が大きくなり，酸素の消費 量が増加するため, 鉄筋の呼び名に応じて，腐食速度の 終局值が小さい方向に移行していることがそれぞれ認め られる。

\section{4. まとめ}

鉄筋コンクリート中の鉄筋の腐食について，腐食によ り消費される酸素を考慮した推定モデルを提案し，ケー ススタディを行った結果を報告した。本研究の範囲で, 以下の事項が言える。

1 ）拡散係数の小さい高品質なコンクリート中の鉄 筋の腐食において，コンクリート表面から拡散に より移動する酸素量から鉄筋の腐食により消費 される分を考慮する鉄筋腐食モデルを提示した。

2 ) 拡散係数の小さい高品質なコンクリートを用い るほど，鉄筋の腐食速度が小さくなり，酸化性の 腐食状態から酸素濃度の低い還元性の腐食状態 


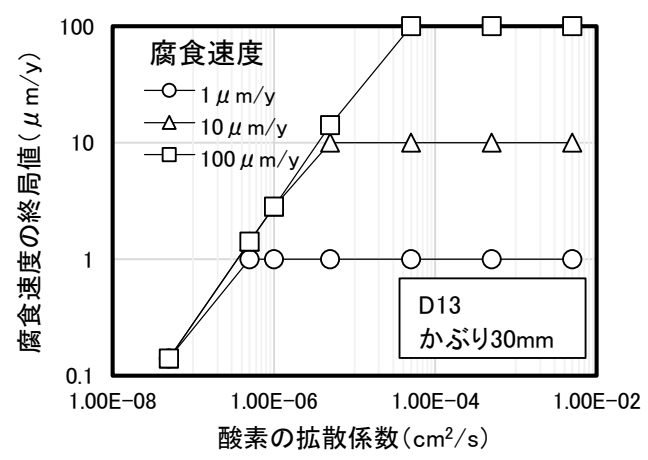

a) かぶり $30 \mathrm{~mm}$

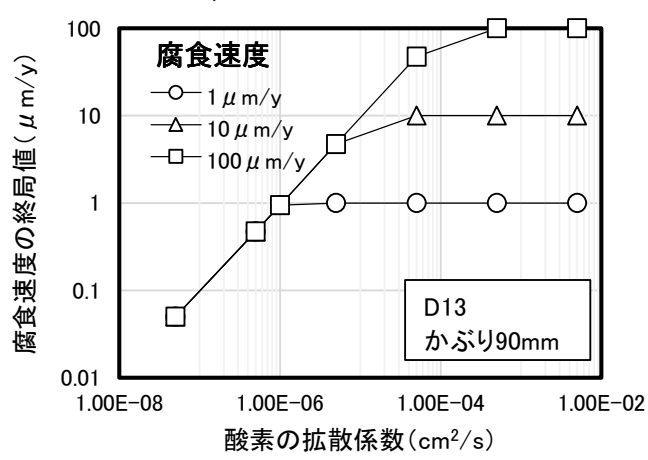

c) かぶり $90 \mathrm{~mm}$

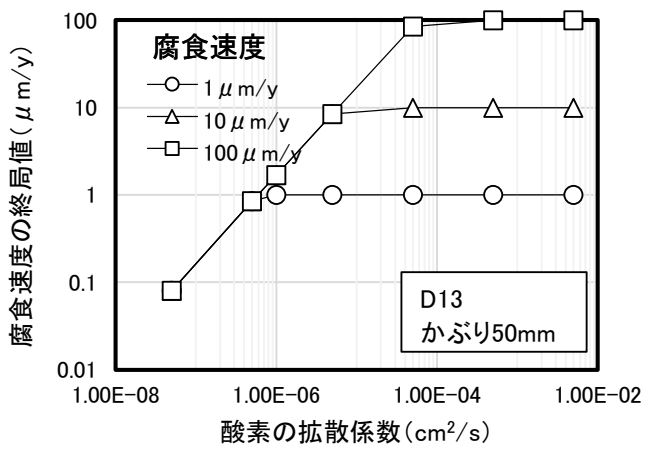

b) かぶり $50 \mathrm{~mm}$

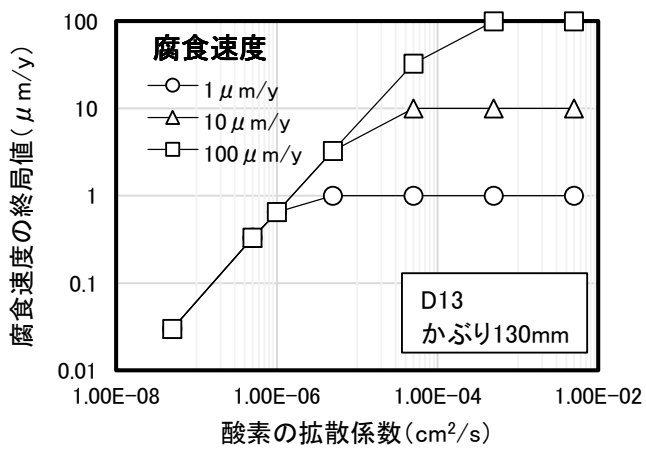

d) かぶり $130 \mathrm{~mm}$

図-7 かぶりごとの腐食速度の終局值（D13についてのみ例示）

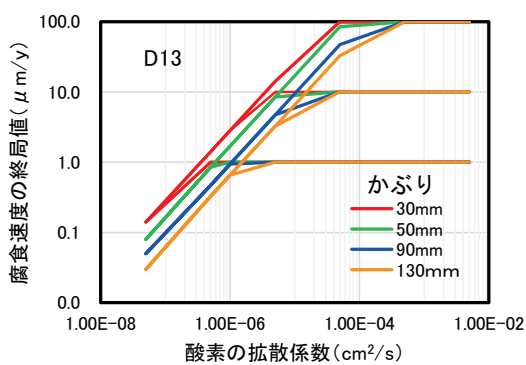

a) D13

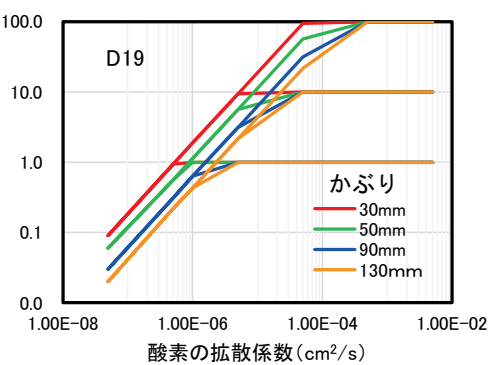

b) D19

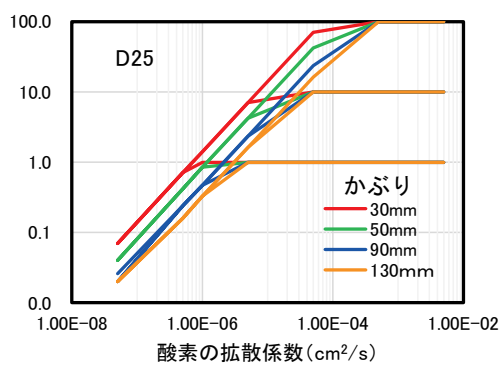

c) D25

図-8＼cjkstart鉄筋の呼び名ごとの腐食速度の終局値

へ移行する可能性が示唆された。

なお，拡散係数の小さい高品質なコンクリートは, ひび割れが生じる鉄筋コンクリート部材では鉄筋腐 食速度の減少効果を十分に発揮させることは一般に 難しい。しかしながら，ひび割れを制御できるプレス トレストコンクリート部材にはコンクリートの高強 度化とともに緻密化を図ることにより，鋼材腐食速度 の減少効果を期待できる。

\section{参 考 文 献}

1） 小林一輔：コンクリート構造物の耐久性診断シリーズ, 森北出版, 1990

2）金子昌章，三浦律彦，藤原愛，山本正史 : 還元性環境での金属腐食 に起因するガス発生量評価，原環センター技術報告書，2004.3

3）伊藤祐二, 三島徹也, 柳博文, 岩城圭介 : 超高性能コンリートの中 性化深さ予測への拡散方程式の適用，コンリート工学年次論文集,
Vol.25, No.1, pp.767-772, 2003

4）佐伯竜彦, 嶋毅, 長瀧重義 : 等価拡散係数を用いたコンリートの塩 分浸透予測手法の検討, コンリート工学年次論文報告集, Vol.20, No.2, pp.859-864, 1998

5）古澤靖彦: コンクリート中の物質移動評価に関する研究の現状，コ ンクリート工学, Vol.37, No.4, pp.3-11, 1999.4

6）石田哲也, Ho Thi Lan Anh : 非線形固定化モデルと濃度依存型拡散 則の連成による塩分浸透解析，コンリート工学年次論文集，Vol.28， No.1，pp.875-880， 2006

7）宮川豊章，松村卓郎，小林和夫，藤井学 : 鋼材腐食からみたコンク リート中での酸素透過性の検討, 土木学会論文集, 第 408 号/V-11, pp.111-120, 1989.8

8）大住道生，魚本健人：酸素拡散理論に基づくコンクリート中の鉄筋 の腐食速度予測法，土木学会論文集，No.648/V-47，pp.1-8，2000.5

9）元路寛，関博，高木言芳：中性化したコンクリートにおける乾湿繰 返し作用による鉄筋腐食に関する研究，土木学会論文集， No.697/V-54, pp.1-11，2002.2 
10) Papadakis, V.G., C.G. Vayenas, and M.N. Fardis : Physical and chemical characteristics affecting the durability of concrete, American Concrete Institute Materials Journal, 88(2), pp.186-196, 1991

11）三原守弘, 西村務, 和田隆太郎, 本田明 : 低酸素かつアルカリ条件 における炭素鋼, ステンレス鋼及びジルカロイからのガス発生率及 び腐食速度の評価，サイクル機構技報, No.15, pp.91-101, 2002.6

12）仁杉嚴 : 支間 $30 \mathrm{~m}$ のプレストレストコンクリート鉄道橋（信楽腺
第一大戸川橋梁) の設計, 施工及びこれに関連して行った実験研究 の報告, 土木学会論文集, 第 27 号, pp.1-56, 1955.7

13）土木学会: 構造物表面のコンクリート品質と耐久性能検証システム 研究小委員会（335 委員会）成果報告書およびシンポジウム講演概 要集，コンクリート技術シリーズ 80, pp.159-163, 2008.4

(原稿受理年月日 : 2021 年 3 月 11 日)

Analytical Estimation of Corrosion Rates of Reinforcing Bars in Concrete

Based on Oxygen Consumption

By Chunhe Li, Yasuyuki Matsunami, Kentaro Suhara and Yukikazu Tsuji

Concrete Research and Technology, Vol.32, 2021

Synopsis: If the amount of oxygen diffusion is greater than the amount of oxygen consumed by oxidative corrosion of reinforcing bars in concrete, the reinforcing bars will continue to undergo oxidative corrosion, but using high quality concrete reduces the amount of oxygen diffusion, which in turn decreases the oxygen concentration and the corrosion rate. In this research, we propose an analytical method to estimate corrosion of reinforcing bars in concrete considering the amount of oxygen consumed by corrosion of reinforcing bars. From the results of case study calculations, corrosion of reinforcing bars may be changed from the oxidative corrosion state into the low oxygen corrosion state in high quality concrete.

Keywords: Corrosion, Oxygen diffusion, Oxygen consumption, Finite difference method, Low oxygen corrosion 